\title{
Essential oil of Origanum majorana L., Illicium verum Hook. f. and Cinnamomum zeylanicum Blume: chemical and antimicrobial characterization
}

FREIRE, J.M. ${ }^{\text {; }}$ CARDOSO, M.G. ${ }^{*}$; BATISTA, L.R ${ }^{2}$; ANDRADE, M.A. ${ }^{1}$

${ }^{1}$ Departamento de Química, ${ }^{2}$ Departamento de Ciência dos Alimentos, Universidade Federal de Lavras, CEP: 37200-000, Lavras-Brasil *mcardoso@ufla.br

RESUMO: Óleos essenciais de Origanum majorana L., Illicium verum Hook. f. e Cinnamomum zeylanicum Blume: caracterização química e antimicrobiana. Óleos essenciais de Origanum majorana L. (manjerona), Illicium verum Hook. f. (anis estrelado) e Cinnamomum zeylanicum Blume (canela) foram obtidos pela técnica de arraste a vapor d'água com aparelho de Clevenger modificado. Foram avaliadas as atividades antimicrobianas de cada um sobre as bactérias Staphylococcus aureus, Escherichia coli e para os fungos Aspergillus flavus e Aspergillus parasiticus, observando o crescimento e/ou inibição micelial, comparandose estes com a placa-padrão (sem óleo). Os óleos essenciais foram analisados em cromatógrafo gasoso acoplado a espectrômetro de massa para a identificação e cromatógrafo gasoso com detector de ionização de chamas para a quantificação dos compostos. Os principais constituintes dos óleos essenciais de manjerona, anis-estrelado e canela foram o 4-terpineol, trans-anetol e aldeído cinâmico, respectivamente. Nos testes in vitro, os óleos essenciais de manjerona e canela promoveram efeito inibitório sobre as bactérias $S$. aureus e $E$. coli, enquanto o óleo essencial de anis estrelado apresentou atividade apenas frente $E$. coli. Os óleos de manjerona, anis estrelado e canela foram efetivos sobre os fungos estudados, apresentando efeito inibitório. A concentração mínima inibitória pra o crescimento micelial de $A$. parasiticus foi de 1 e 0,01 $\mu \mathrm{L}$ $\mathrm{mL}^{-1}$ para os óleos de anis-estrelado e canela, respectivamente. Enquanto a concentração mínima inibitória para A. parasiticus foi de 0,25; 2 e $2 \mu \mathrm{L} \mathrm{mL}^{-1}$ para os óleos de canela, anis-estrelado e manjerona, respectivamente.

Palavras-chave: Origanum majorana, Illicium verum, Cinnamomum zeylanicum, concentração mínima inibitória

ABSTRACT: Essential oils of Origanum majorana L. (marjoram), Illicium verum Hook. f. (staranise) and Cinnamomum zeylanicum Blume (cinnamon) were obtained by steam distillation using a modified Clevenger device. The antimicrobial activity of each oil was evaluated against the bacteria Staphylococcus aureus, Escherichia coliand the fungi Aspergillus flavus and Aspergillus parasiticus by observing their growth and/or mycelial inhibition through comparison with the standard dish (without oil). The essential oils were analyzed using a gas chromatograph coupled to a mass spectrometer for identification and coupled to a flame ionization detector for quantification. The major constituents of marjoram, star-anise and cinnamon essential oils were 4-terpineol, transanetole and cinnamic aldehyde, respectively. In in vitro tests, essential oils of marjoram and cinnamon promoted an inhibitory effect on the bacteria S. aureus and E. coli, while the essential oil of star-anise presented activity only against E. coli. Marjoram, star-anise and cinnamon oils were effective against the studied fungi, presenting an inhibitory effect. The minimal inhibitory concentration for the mycelial growth of $A$. parasiticus was 1 and $0.01 \mu \mathrm{L} \mathrm{mL}^{-1}$ for star-anise and cinnamon oils, respectively. The minimal inhibitory concentration for $A$. parasiticus was $0.25,2$ and $2 \mu \mathrm{L} \mathrm{mL}-1$ for cinnamon, star-anise and marjoram oils, respectively.

Key words: Origanum majorana, Illicium verum, Cinnamomum zeylanicum, minimal inhibitory concentration

Recebido para publicação em 19/08/2009

Aceito para publicação em 08/09/2010

Rev. Bras. PI. Med., Botucatu, v.13, n.2, p.209-214, 2011. 


\section{INTRODUCTION}

Essential oils are volatile compounds extracted from plants by means of different techniques; they are widely important in phytosanitary control, enabling the development of other techniques to decrease the negative effects of oxidants, radicals and microorganisms, causing losses to food industries (Pereira et al., 2008).

Currently consumers have demanded the use of natural foods with a low level of chemical additives, which frequently possess carcinogenic agents and a long shelf life. The food legislation has restricted the use of certain synthetic antimicrobials based on the possibility of toxicity (Oussalah et al., 2007; Oliveira et al., 2010). Thus, phytochemical research presents itself as a useful method, seeking analytical and instrumental techniques which allow both the isolation and elucidation of a number of compounds. Therefore, essential oils found in plant seasoning have aroused interest in food industries for presenting antibacterial, antifungal and antioxidant properties, making the study of the inhibitory effect of those oils in microorganisms an alternative to reduce the use of chemical additives in foods (Pereira et al., 2008).

Among aromatic species, Illicium verum Hook. f., Origanum majorana L. and Cinnamomum zeylanicum Blume, commonly known as star-anise, marjoram and cinnamon, present a number of biological activities, reflections of their chemical diversity. Among other components, anetol (staranise), 4-terpineol (marjoram) and cinnamic aldehyde (cinnamon) stand out. Food industries have explored the essential oil of those plants for their confirmed antibacterial and antifungal activity (Koketsu et al., 1997; Tuan et al., 1997; Tepe et al., 2006).

Thus, the present study aimed to investigate the chemical composition of the essential oils of Illicium verum, Origanum majorana and Cinnamomum zeylanicum, as well as their inhibitory effect on the growth of Staphylococcus aureus, Escherichia coli, Aspergillus flavus and Aspergillus parasiticus.

\section{MATERIAL AND METHOD}

\section{Plant material}

The plant material, Illicium verum, Origanum majorana and Cinnamomum zeylanicum, were purchased in the dry form in the city market of Lavras, Minas Gerais State, Brazil, during the same period. Cinnamon and star-anise were obtained from "Comercial Santa Bárbara Ltda" (Franca, São Paulo State, Brazil), while marjoram was acquired from "Kiflor Indústria e Comércio de Produtos Alimentícios Ltda" (Campo Belo, Minas Gerais, Brazil).
The employed method was steam distillation using a Clevenger-type system coupled to a roundbottomed balloon with capacity of 6 liters (Guimarães et al., 2008); the samples were used in the same form as purchased. Extraction was performed for 2 hours, maintaining the boiling solution. Afterwards, the hydrolate was collected and centrifuged in a horizontal crosshead centrifuge at $965.36 \times \mathrm{g}$ for 5 minutes.

\section{Identification and quantification of chemical constituents}

A gas chromatograph coupled to a mass spectrometer (GC/MS), Shimadzu GC-17A model, was utilized under the following operational conditions: capillary column DB5 (30 m X $0.25 \mathrm{~mm})$, injector temperature of $220^{\circ} \mathrm{C}$; column temperature $240^{\circ} \mathrm{C}$; carrier gas helium (1 $\left.\mathrm{mL} \mathrm{min}^{-1}\right)$; split rate 1:10; injected volume of $1 \mu \mathrm{L}$ and column pressure of $100.2 \mathrm{KPa}$. MS conditions were: impact energy of $70 \mathrm{eV}$; decomposition velocity 1000 ; decomposition interval of 0.50; and decomposed fragments of $45 \mathrm{Da}$ and $450 \mathrm{Da}$. A series of standards of hydrocarbons $\left(\mathrm{C}_{9} \mathrm{H}_{20} \ldots \ldots . \mathrm{C}_{26} \mathrm{H}_{54}\right)$ was injected under the same conditions. The obtained spectra were compared with the data bank of Wiley 229 library using Kovat's index, calculated for each constituent according to Adams (2007).

For quantitative analyses, a gas chromatograph Shimadzu GC 17A equipped with a flame ionization detector (FID) was used under the operational conditions of GC/MS. The quantification of each constituent was obtained by means of normalization of areas (\%).

\section{Maintenance of cultures and standardization Bacteria}

S. aureus strains ATCC 25923 and E. coli ATCC 25992 were maintained under refrigeration $\left(4^{\circ} \mathrm{C}\right)$ and transplanted in brain and heart infusion broth (BHI), keeping incubated at $37^{\circ} \mathrm{C}$ for 24 hours. Then, E. coli and $S$. aureus cultures were plated on Eosin Methylene Blue Agar (EMB) and Plate Count Agar (PCA) media, respectively. Three colonies of the same morphological type, which were transferred to $5 \mathrm{~mL}$ of tryptic soybean broth (TSA), were screened. The tubes were incubated at $37^{\circ} \mathrm{C}$ until reaching or exceeding the turbidity of a 0.5 standard McFarland solution resulting in a suspension of $10^{8} \mathrm{CFU} \mathrm{mL}^{-1}$ (NCCLS, 2003).

\section{Fungi}

The fungal strains $A$. flavus and $A$. parasiticus were maintained in slant medium CZAPEK-DOX (CYA) added of yeast extract in $\mathrm{BOD}$ at $25^{\circ} \mathrm{C}$. With the aid of a loop, the strains were transferred to Petri dishes containing $20 \mathrm{~mL}$ of the same culture medium for

\section{Extraction of essential oils}

Rev. Bras. PI. Med., Botucatu, v.13, n.2, p.209-214, 2011. 
activation and verification of contamination. The dishes were incubated at $25^{\circ} \mathrm{C}$ for 7 days.

\section{Inhibitory effect of essential oils against $E$. coli and S. aureus}

An aliquot of $5 \mathrm{~mL}$ TSA broth containing $10^{8}$ CFU mL ${ }^{-1}$ was transferred to the Mueller Hinton culture medium and the employed methodology was agar diffusion. Slots or deposition well of essential oils were done in the agar with the aid glass beads previously removed. Then, $10 \mu \mathrm{L}$ of the essential oils diluted in dimethyl sulfoxide (DMSO) were transferred to the slots.

Mueller Hinton agar was incubated with the test cultures ( $S$. aureus and $E$. colli) and deposited onto the layer of the same agar with the slots. The latter were filled with the oils at the concentrations of $0.1,0.5,1,5,10,20,30,40$ and $50 \%$. The dishes were incubated in $\mathrm{BOD}$ at $37^{\circ} \mathrm{C}$ for 24 hours and the diameters of halos were measured (Ogunwande et al., 2005). A relative control to which $10 \mu \mathrm{L}$ of DMSO was applied and an absolute control without solvent were similarly incubated.

Inhibitory effect of essential oils against $A$. flavus and $A$. parasiticus

The fungicidal properties of star-anise and marjoram essential oils were tested at the concentrations of $0,0.1,0.25,0.5,1$ and $2 \mu \mathrm{L} \mathrm{mL}^{-1}$. Cinnamon essential oil was tested at the concentrations of $0,0.005,0.01,0.02,0.04$ and 0.08 $\mu \mathrm{L} \mathrm{mL}^{-1}$ and, similarly to these preliminary tests, higher concentrations were lethal to $A$. flavus; its Minimal Inhibitory Concentration (MIC) could not be determined. As regards $A$. parasiticus, the concentrations of $0,0.1$, $0.25,0.5,1$ and $2 \mu \mathrm{L} \mathrm{mL}^{-1}$ were used for all essential oils. A check with the standard dish (DMSO) was performed.

The essential oils diluted in DMSO were added to the culture medium at a temperature of about $45^{\circ} \mathrm{C}$, and $20 \mathrm{~mL}$ of that culture medium were added to each dish; then, the fungi were inoculated at the center of those dishes which were incubated in BOD at $25^{\circ} \mathrm{C}$ for 7 days. The relative check (DMSO) was incorporated at the dosage of $2.5 \mu \mathrm{g} \mathrm{mL}^{-1}$ substrate (Wang et al., 2005).

Evaluations were performed after 7 days from the establishment of the experiment by means of diametrically opposed measurements of mycelial growth, and the means were calculated from each two opposed measures.

\section{RESULT AND DISCUSSION}

Identification and quantification of the constituents of essential oils The chemical composition of the essential oils obtained by GC and GC/MS analyses are presented in Table 1. The main compounds identified were marjoram essential oil, 4terpineol (34.23\%) followed by $\gamma$-terpinene $(14.28 \%)$; star-anise oil, trans-anetol (90.41\%) followed by limonene (2.652\%); cinnamon oil, cinnamic aldehyde (87.7\%) followed by $\alpha$-pinene (7.98\%).

TABLE 1. Chemical composition of marjoram, star-anise and cinnamon essential oils.

\begin{tabular}{lccc}
\hline \multicolumn{4}{c}{ Concentration (\%) } \\
Compound & Marjoram & Star-an ise & Cinnamon \\
\hline Sabinene & 5.29 & - & - \\
$\alpha$ - terpinene & 8.17 & - & - \\
$\mathrm{P}$ - cymene & 3.47 & - & - \\
Limonene & 3.11 & 2.652 & - \\
$\gamma$ - terpinene & 14.28 & - & - \\
Cis-sabinene & 3.02 & - & - \\
Trans-sabinene & 8.81 & - & - \\
4 - terpineol & 34.23 & 0.295 & - \\
$\alpha$ - terpineol & 5.30 & - & - \\
Trans-cariofilene & 2.68 & - & - \\
$\alpha$ - pinene & - & 0.349 & 7.98 \\
Metil-chavicol & - & 1.261 & - \\
Trans-anetol & - & 90.41 & - \\
Cinnamic aldehyde & - & - & 87.70 \\
$\beta$ - pinene & - & - & 4.23 \\
\hline
\end{tabular}

Rev. Bras. Pl. Med., Botucatu, v.13, n.2, p.209-214, 2011. 


\section{Biological activity}

\section{Inhibitory effect of essential oils against A. flavus and A. parasiticus}

Based on the data shown in Table 2, A. flavus had its mycelial development affected by star-anise essential oil from $0.1 \mu \mathrm{L} \mathrm{mL}^{-1}$ and had a MIC of $1 \mu \mathrm{L}$ $\mathrm{mL}^{-1}$.

As regards marjoram essential oil (Table 2), for $A$. flavus there was a tendency towards increase in the mycelial development inhibition rates proportional to the increase in the tested concentrations, and MIC could not be determined. There were significant differences among all the analyzed concentrations.

TABLE 2. Average values of the mycelial growth diameter of $A$. flavus related to the concentration.

\begin{tabular}{crr}
\hline \multicolumn{3}{c}{ Formation of inhibition halo $(\mathrm{cm})$} \\
$\begin{array}{c}\text { Concentration } \\
\left(\mu \mathrm{mL}^{-1}\right)\end{array}$ & Marjoram & Anis \\
\hline 0 & $7,64 \mathrm{f}$ & $7,64 \mathrm{~b}$ \\
0.1 & $5.1 \mathrm{e}$ & $5.68 \mathrm{~b}$ \\
0.25 & $3.19 \mathrm{~d}$ & $2.49 \mathrm{a}$ \\
0.5 & $2.36 \mathrm{c}$ & $0.95 \mathrm{a}$ \\
1.0 & $1.86 \mathrm{~b}$ & $0 \mathrm{a}$ \\
2.0 & $0.9 \mathrm{a}$ & $0 \mathrm{a}$ \\
\hline
\end{tabular}

Means followed by the same small letter in the column do not differ at $5 \%$ probability according to Scott-Knott test (1974).

When cinnamon essential oil was added to A. flavus culture medium (Table 3), development was affected from the concentration of $0.005 \mu \mathrm{L} \mathrm{mL}^{-1}$ but MIC could not be determined. The concentration of $0.005 \mu \mathrm{L} \mathrm{mL}^{-1}$ yielded significant differences relative to the other concentrations.

TABLE 3. Average values of the mycelial growth diameter of $A$. flavus related to the concentration of cinnamon essential oil.

\begin{tabular}{cc}
\hline $\begin{array}{c}\text { Formation of inhibition halo }(\mathrm{cm}) \\
\text { Concentration } \\
\left(\mu \mathrm{LL}^{-1}\right)\end{array}$ & Cinnamon \\
\hline 0 & $7.64 \mathrm{c}$ \\
0.005 & $3.99 \mathrm{~b}$ \\
0.01 & $3.38 \mathrm{a}$ \\
0.02 & $3.33 \mathrm{a}$ \\
0.04 & $3.01 \mathrm{a}$ \\
0.08 & $2.91 \mathrm{a}$ \\
\hline
\end{tabular}

Means followed by the same small letter do not differ at $5 \%$ probability according to Scott-Knott test (1974).
As shown in Table 4, marjoram essential oil presented a MIC value of $2 \mu \mathrm{L} \mathrm{mL}^{-1}$ for $A$. parasiticus growth. All the treatments showed significant differences.

Star-anise essential oil had a MIC of $2 \mu \mathrm{L}$ $\mathrm{mL}^{-1}$ against $A$. parasiticus.

Cinnamon essential oil presented total inhibition (100\%) of the mycelial development of the tested fungi from the concentration of $0.25 \mu \mathrm{L} \mathrm{mL}^{-1}$, confirming previous data on the efficacy of that seasoning when added in the form of powder and essential oil (Patkar et al.,1993; Sinha et al., 1993; Souza \& Inneco, 2004).

Evaluating the antifungal activity of Foeniculum vulgare (anise) essential oil, which has trans-anetol (70.1\%) as major compound, an $87.5 \%$ inhibition of $A$. flavus mycelial growth was found at a concentration of $2 \mu \mathrm{L} \mathrm{mL}^{-1}$ (Singh et al., 2006).

TABLE 4. Average values of the mycelial growth diameter of $A$. parasiticus related to the concentration.

\begin{tabular}{crrr}
\hline \multicolumn{4}{c}{ Formation of inhibition halo $(\mathrm{cm})$} \\
\hline $\begin{array}{c}\text { Concentration } \\
\left(\mu \mathrm{L} \mathrm{mL}^{-1}\right)\end{array}$ & Marjoram & Star-anise & Cinnamon \\
\hline 0 & $7.98 \mathrm{f}$ & $7.98 \mathrm{f}$ & 7.98 \\
0.1 & $6.28 \mathrm{e}$ & $6.31 \mathrm{e}$ & 5.61 \\
0.25 & $2.06 \mathrm{~d}$ & $2.44 \mathrm{~d}$ & 0 \\
0.5 & $1.45 \mathrm{c}$ & $1.98 \mathrm{c}$ & 0 \\
1.0 & $0.45 \mathrm{~b}$ & $1.03 \mathrm{~b}$ & 0 \\
2.0 & $0 \mathrm{a}$ & $0 \mathrm{a}$ & 0 \\
\hline
\end{tabular}

Means followed by the same small letter do not differ at $5 \%$ probability according to Scott-Knott test (1974).

\section{Bactericidal activity of essential oils against $E$. coli and $S$. aureus}

As regards star-anise essential oil against $S$. aureus, there was a resistance of that bacterium and no halo formation on the dish, also verified for the control dish (Table 5).

As shown in Table 5, cinnamon essential oil did not promote growth inhibition at the concentrations: $0.1,0.5$ and $1 \%$. For other concentrations $(5,10,20$, 30,40 and $50 \%$ ), there was the formation of inhibition halo, not showing significant differences among treatments 5, 10, 20, 30 and 50\%, which differed from the concentration of $40 \%$. The concentrations of 30 and $40 \%$ were most effective, differing significantly from the others.

Marjoram essential oil at the concentrations of $0.1,0.5$ and $1 \%$ presented no biological effect on S. aureus. The concentrations of $5 \%$ and $10 \%$ presented no significant difference in halo size; however, the concentrations of 20,30 and $40 \%$ showed a size variation relative to the results of the 
first group, but values remained constant among them; the concentration of $50 \%$ presented the greatest effect against that bacterium when compared to the others.

Based on the data shown in Table 6, for marjoram essential oil MIC was $1 \%$, with significant difference among treatments. As to the bactericidal effect of cinnamon essential oil on $E$. coli, the concentrations $0.1,0.5$ and $1 \%$ did not promote bacterial growth inhibition; the MIC was $5 \%$ which showed a significant difference relative to the other concentrations. Star-anise essential oil promoted growth inhibition from the concentration of $0.5 \%$.

The best inhibition results for bacteria were ascribed to camphor essential oil, which has cinnamic aldehyde as major compound. Both cinnamic

TABLE 5. Average values of inhibition halo diameter of essential oils against $S$. aureus.

\begin{tabular}{ccrr}
\hline \multicolumn{4}{c}{ Formation of inh ibition halo $(\mathrm{cm})$} \\
\hline Concentration (\%) & Star-anise & Marjoram & Cinnamon \\
\hline 0 & 0 & $0 \mathrm{a}$ & $0 \mathrm{a}$ \\
0.1 & 0 & $0 \mathrm{a}$ & $0 \mathrm{a}$ \\
0.5 & 0 & $0 \mathrm{a}$ & $0 \mathrm{a}$ \\
1.0 & 0 & $0 \mathrm{a}$ & 0 \\
5.0 & 0 & $0.9 \mathrm{~b}$ & $4.2 \mathrm{~b}$ \\
10.0 & 0 & $1.13 \mathrm{bc}$ & $4.3 \mathrm{~b}$ \\
20.0 & 0 & $1.2 \mathrm{c}$ & $4.4 \mathrm{~b}$ \\
30.0 & 0 & $1.2 \mathrm{c}$ & $5.18 \mathrm{bc}$ \\
40.0 & 0 & $1.33 \mathrm{c}$ & $5.43 \mathrm{c}$ \\
50.0 & 0 & $1.6 \mathrm{a}$ & $4.4 \mathrm{~b}$ \\
\hline
\end{tabular}

Means followed by the same small letter in the column do not differ at $5 \%$ probability according to Tukey's test (1975).

TABLE 6. Average values of inhibition halo diameter of the essential oils against $E$. coli.

\begin{tabular}{crrr}
\hline \multicolumn{4}{c}{ Formation of inh ibition halo (cm) } \\
\hline Concentration (\%) & Marjoram & Star-anise & Cinnamon \\
\hline 0 & $0 \mathrm{e}$ & $0 \mathrm{~d}$ & $0 \mathrm{e}$ \\
0,1 & $0 \mathrm{e}$ & $0 \mathrm{~d}$ & $0 \mathrm{e}$ \\
0,5 & $0 \mathrm{e}$ & $0.6 \mathrm{c}$ & $0 \mathrm{e}$ \\
1.0 & $1.0 \mathrm{~d}$ & $0.7 \mathrm{c} \mathrm{b}$ & $0 \mathrm{e}$ \\
5.0 & $1.05 \mathrm{~d}$ & $088 \mathrm{~b} \mathrm{a}$ & $2.2 \mathrm{~d}$ \\
10.0 & $1.1 \mathrm{~d} \mathrm{c}$ & $0.85 \mathrm{~b} \mathrm{a}$ & $2.43 \mathrm{c}$ \\
20.0 & $1.3 \mathrm{c}$ & $0.88 \mathrm{~b} \mathrm{a}$ & $2.5 \mathrm{c}$ \\
30.0 & $1.45 \mathrm{ba}$ & $0.85 \mathrm{~b} \mathrm{a}$ & $2.83 \mathrm{~b}$ \\
40.0 & $1.3 \mathrm{c} \mathrm{b}$ & $0.9 \mathrm{~b} \mathrm{a}$ & $2.83 \mathrm{~b}$ \\
50.0 & $1.6 \mathrm{a}$ & $0.95 \mathrm{a}$ & $3.05 \mathrm{a}$ \\
\hline
\end{tabular}

Means followed by the same small letter in the column do not differ at $5 \%$ probability according to Tukey's test (1975). aldehyde and eugenol were compounds also found in the essential oils of Cinnamomum cassia and Cinnamomum verum (Oussalah et al., 2007). The latter evaluated the activity of those oils in controlling four pathogenic bacteria (E. coli, Salmonella typhimurium, $S$. aureus and Listeria monocytogenes) and found toxicity against the studied microorganisms.

In an investigation about the antibacterial activity of Origanum vulgare essential oil against $S$. aureus and E. coli, 4-terpineol (26.3\%) stood out (Pereira et al., 2008).

The major compound of Pimpinella anisum (anise) essential oil was trans-anetol (82.8\%); the same was present in Illicum verum (star-anise). That compound was responsible for the antimicrobial activity against Streptococcus pneumoniae, Bacillus cereus, Acinetobacter Iwoffii, E. coli, Klebsiella pneumoniae, Clostridium perfingens, Candida albicans and Candida krusei (Tepe et al., 2006).

The studied oils had inhibitory effect on the studied microorganisms and therefore can be considered an alternative for the microbiological control of food.

\section{ACKNOWLEDGEMENT}

The authors would like to thank CAPEs, CNPq and FAPEMIG - for financial support.

\section{REFERENCE}

ADAMS, R.P. Identification of essential oils components by gas chromatography/ mass spectroscopy. 4.ed. Carol Stream: Allured, 2007. 469p.

GUIMARÃES, L.G.L. et al. Influência da luz e da temperatura sobre a oxidação do óleo essencial de capim-limão (Cymbopogon citratus (DC.) Stapf). Química Nova, v.31, n.6, p.1476-80, 2008.

KOKETSU, M. et al. Óleos essenciais de cascas e folhas de canela (Cinnamomum verum Presl) cultivada no Paraná. Ciências e Tecnologia de Alimentos, v.17, n.3, p.281-5, 1997.

NCCLS. Methods for dilution antimicrobial susceptibility tests for bacteria that grow aerobically. 6.ed. Wayne: NCCLS, 2003. 49p.

OGUNWANDE, I.A. et al. Studies on the essential oils composition, antibacterial and cytotoxicity of Eugenia uniflora L. The International Journal of Aromatherapy, v.15, n.2, p.147-52, 2005.

OLIVEIRA, M.M.M. et al. Disinfectant action of Cymbopogon sp. essential oils in different phases of biofilm formation by Listeria monocytogenes on stainless steel surface. Food Control, v.21, n.4, p.549-53, 2010.

OUSSALAH, M. et al. Inhibitory effects of selected plant essential oils on the growth of four pathogenic bacteria: E. coliO157:H7, Salmonella typhimurium, Staphylococcus aureus and Listeria monocytogenes. Food Control, v.62, n.2, p.414-20, 2007.

PATKAR, K.L. et al. Effect of spice oils on growth and 
aflatoxin $\mathrm{B}_{1}$ production by Aspergillus flavus. Letters in Applied Microbiology, v.17, n.3, p.49-51, 1993.

PEREIRA, A.A. et al. Caracterização química e efeito inibitório de óleos essenciais sobre o crescimento de Staphylococcus aureus e Escherichia coli. Ciência e Agrotecnologia, v.32, n.3, p.887-93, 2008.

SCOTT A.J.; KNOTT M. Cluster analysis method for grouping means in the analysis of variance. Biometrics, v.30, n.1, p.507-12, 1974.

SINGH, G. et al. Chemical constituents, antifungal and antioxidative potential of Foeniculum vulgare volatile oil and its acetone extract. Food Control, v.17, n.4, p.745-52, 2006.

SINHA, K.K. et al. The effect of clove and cinnamon oils on growth of and aflatoxin production by Aspergillus flavus. Letters in Applied Microbiology, v.16, n.2, p.1147, 1993.

SOUZA, M.R.A; INNECO, R. Influência de períodos de secagem de folha no óleo essencial de erva-cidreira (quimiotipo limoneno-carvona). Revista Ciência Agronômica, v.34, n.1, p.5-11, 2004.

TEPE, B. et al. Screening of the antioxidative and antimicrobial properties of the essential oils of Pimpinella anisetum and Pimpinella flabellifolia from Turkey. Food Chemistry, v.97, n.4, p.719-24, 2006.

TUKEY, J.W. Mathematics and picturing data. In: INTERNATIONAL CONGRESS OF MATHEMATICAL, 1975, Vancouver. Proceedings ... Vancouver, 1975. v.2, p.523-31. TUAN, D.Q.; ILANGANTILEKE, S.G. Liquid $\mathrm{CO}_{2}$ extraction of essential oil from star anise fruits (Illicium verum $\mathrm{H}$.) Journal of Food Engineering, v.31, n.1, p.47-57, 1997.

WANG, S.Y. et al. Antifungal activities of essential oils theirconstituents from Indigenus cinnamom (Cinnamomum osmoplaloeum) leaves against wood decay fungi. Bioresource Tecnology, v.96, n.2, p.813-8, 2005. 